\title{
Motes percentage and ginning outturn as affected with cotton cultivar and location
}

\author{
HossamEl-Din H. El-Feky \\ Cotton Research Institute, Agricultural Research Center, Ministry of Agriculture and Land Reclamation, Giza, Egypt; \\ hossamhhf@hotmail.com
}

Received 30 April 2010; revised 3 May 2010; accepted 7 May 2010.

\begin{abstract}
The present study was conducted to analyze cotton cultivar and location differences in motes, and to determine the relationships among these and ginning outturn. Therefore, the seed cotton of five promising hybrids namely; G.77 × Pima S6 and G.84 $\times($ G.74 $\times$ G.68) growing in [Kafr ElSheikh - Kafr El-Dawar - Etay El-Barood - Damietta], G.89 × Pima S6 growing in [El-Sharkia El-Gharbiya - El-Dakahliya - El-Monofiya], G.83 $\times$ $(\mathbf{G . 7 5} \times 5844) \times \mathbf{G . 8 0}$ and $\mathrm{G} .90 \times$ Australian growing in [Sohag - El-Minia - Beni-Sueif - ElFaium] were used in this study. The results obtained indicate that the varieties exhibited different behavior responses to environmental conditions. On the whole, environmental factors associated with differences in place of growth, appeared to have much more influence on the number of motes than did varietal factors. Most of the locks for the promising hybrids at the different locations tend to cluster around the mean of 6 or 7 seeds per lock. There is a fairly marked tendency for the lock index, lint weight and lint percentage to decrease as the motes percentage increase. On the other hand, most of the promising hybrids under study tend to increase in the seed index as the motes percentage increase. However, the increasing in seed index as a result of the increasing in motes percentage for some cotton cultivars growing at different environments could be explain the difference in behavior for these cotton cultivars in lint percentage.
\end{abstract}

Keywords: Cotton Cultivar; Ginning Outturn; Location; Lock Index; Motes; Seed Index

\section{INTRODUCTION}

Cotton ginning outturn is much used measurement in cotton production, marketing and ginning. Ginning out- turn is the percentage of ginned lint obtained from a mass of seed cotton. However, plant location plays a serious role on ginning outturn. The number of seeds per boll is a component of both cotton yield and fiber quality and is a function of the number of locules (carpels) per boll and the number of ovules per locule [1]. Both cultivar and environment contribute to the variation in the number of seeds per boll. Weather conditions affect ovule development, pollen fertility, and pollen dispersal [1-3].

Motes are defined as ovules that have not been fertilized or underdeveloped seed in which embryos ceased growth shortly after fertilization [4,5]. Mangialardi and Meredith [6] reported that there was an interaction between variety and year for the number of motes. Davidonis et al. [7] found discrepancies between reports relating mote frequency and boll location. They concluded from their study that long fiber motes were related to the timing and intensity of environmental stress, not harvest date or boll location. Bolek [8] stated that motes are cotton (Gossypium spp.) ovules that fail to ripen into mature seeds. These aborted ovules represent a loss in yield and can cause imperfections in yarn and cloth quality.

Mote frequencies and mote weights were affected by varieties and years. Percy [9] found that high ovule abortionn rates (mote production) observed in Gossypium hirsutum L. x G. barbadense L. interspecific $\mathrm{F}_{1}$ hybrids (ISH) have generally been attributed to the presence of genetic incompatibilities between the two parent species. Other causes of mote production within G. hirsutum and G. barbadense cottons are adverse environmental factors. The environmental variance in seed index was generally small [10]. In contrast to [10], Turner et al. [11] reported that the variance in seed index due to cultivar and cultivar $\mathrm{x}$ location were highly significant. However, Understanding factors controlling seed abortion is of importance to physiologists, breeders, producers, and ginners.

Thus, the objectives of this research were to 1 ) determine the frequency of seeds, motes production and ginning outturn as affected with cotton cultivar and location, and 2) determine if seed weight per locules was related to ginning outturn. 


\section{MATERIALS AND METHODS}

The present study was conducted to determine variation in motes number (motes per lock), and its effect on ginning outturn for seed-cotton samples, representing different varieties and environments (locations). The varieties and locations are listed in the following table.

\begin{tabular}{|c|c|c|}
\hline No. & Cotton cultivar & location \\
\hline 1 & H1: G.77 × Pima S6 & $\begin{array}{c}\text { Kafr El-Sheikh } \\
\text { Kafr El-Dawar } \\
\text { Etay El-Barood } \\
\text { Damietta }\end{array}$ \\
\hline 2 & H2: G.84 × (G.74 × G.68) & $\begin{array}{c}\text { Kafr El-Sheikh } \\
\text { Kafr El-Dawar } \\
\text { Etay El-Barood } \\
\text { Damietta }\end{array}$ \\
\hline 3 & H4: G.89 × Pima S6 & $\begin{array}{c}\text { El-Sharkia } \\
\text { El-Gharbiya } \\
\text { El-Dakahliya } \\
\text { El-Monofiya }\end{array}$ \\
\hline 4 & $\begin{array}{c}\text { H6: } \mathrm{G.83} \times(\mathrm{G} .75 \times 5844) \times \\
\text { G.80 }\end{array}$ & $\begin{array}{c}\text { Sohag } \\
\text { El-Minia } \\
\text { Beni-Sueif } \\
\text { El-Faium }\end{array}$ \\
\hline 5 & H8: G.90 × Australian & $\begin{array}{c}\text { Sohag } \\
\text { El-Minia } \\
\text { Beni-Sueif } \\
\text { El-Faium }\end{array}$ \\
\hline
\end{tabular}

The present study was carried out in 2008 at the Cotton Ginning Research Section, Cotton Research Institute, Agricultural Research Center. The sample consists of 100 locks and the seeds in each lock were numbered and sorted according to the presence or absence of motes. The percentage of locks with motes was determined. Measurements made included: potential seed number (determined to be the number of seed plus motes per locule), ovule abortion rate (expressed as the percent of the potential seed number per locule which were motes), lock index (the weight, in grams, of 100 locks), lint weight per 100 locks and seed index (the weight, in grams, of 100 seeds). The samples were ginned by the McCarthy reciprocating knife 16-inch roller gin stand. The lint percentage (ginning outturn) was calculated for each sample by dividing the weight of the ginned lint by the initial seed cotton weight.

\section{RESULTS AND DISCUSSION}

The present investigation was conducted to determine to what degree environment and cotton cultivar contributes to the mote numbers and ginning outturn.

\subsection{Variations in the Number of Motes in Seed Cottons}

Varietal differences in the number of motes formed are very striking (Table 1, Figures 1-8). The average per-

Table 1. Lock properties and lint percentage as affected with the cotton cultivar and location.

\begin{tabular}{|c|c|c|c|c|c|c|c|}
\hline Promising Hybrid & Location & Seed (\%) & Motes (\%) & $\begin{array}{c}\text { Lock } \\
\text { index (g) }\end{array}$ & $\begin{array}{c}\text { Lint } \\
\text { weight (g) }\end{array}$ & $\begin{array}{c}\text { Seed } \\
\text { index (g) }\end{array}$ & $\begin{array}{c}\text { Lint } \\
\text { percentage } \\
(\%)\end{array}$ \\
\hline \multirow[t]{5}{*}{ G.77 × Pima S6 } & Kafr El-Sheikh & 70.6 & 29.4 & 89.1 & 32.2 & 10.5 & 36.1 \\
\hline & Kafr El-Dawar & 76.4 & 23.6 & 90.9 & 33.4 & 9.6 & 36.7 \\
\hline & Etay El-Barood & 81.3 & 18.8 & 97.4 & 36.1 & 9.4 & 37.0 \\
\hline & Damietta & 73.3 & 26.8 & 77.2 & 26.7 & 8.2 & 34.6 \\
\hline & Mean & 75.4 & 24.7 & 88.7 & 32.1 & 9.4 & 36.1 \\
\hline \multirow{5}{*}{ G.84 × (G.74 × G.68) } & Kafr El-Sheikh & 78.8 & 21.3 & 102.9 & 38.5 & 10.4 & 37.4 \\
\hline & Kafr El-Dawar & 81.5 & 18.5 & 109.8 & 41.0 & 10.3 & 37.3 \\
\hline & Etay El-Barood & 84.8 & 15.3 & 113.5 & 40.8 & 10.8 & 35.9 \\
\hline & Damietta & 79.9 & 20.1 & 95.6 & 33.8 & 9.6 & 35.4 \\
\hline & Mean & 81.3 & 18.8 & 105.5 & 38.5 & 10.3 & 36.5 \\
\hline \multirow[t]{5}{*}{ G.89 × Pima S6 } & El-Sharkia & 80.9 & 19.1 & 117.7 & 45.5 & 11.1 & 38.7 \\
\hline & El-Gharbiya & 77.3 & 22.8 & 92.0 & 35.8 & 9.0 & 38.9 \\
\hline & El-Dakahliya & 75.8 & 24.3 & 91.0 & 34.8 & 9.2 & 38.2 \\
\hline & El-Monofiya & 72.1 & 27.9 & 100.7 & 39.3 & 10.6 & 39.0 \\
\hline & Mean & 76.5 & 23.5 & 100.4 & 38.9 & 10.0 & 38.7 \\
\hline \multirow{5}{*}{$\mathrm{G} .83 \times(\mathrm{G} .75 \times 5844) \times \mathrm{G} .80$} & Sohag & 74.4 & 25.6 & 88.6 & 36.1 & 8.8 & 40.8 \\
\hline & El-Minia & 81.3 & 18.8 & 75.3 & 31.0 & 6.1 & 41.2 \\
\hline & Beni-Sueif & 73.5 & 26.5 & 98.8 & 39.6 & 9.7 & 40.1 \\
\hline & El-Faium & 72.1 & 27.9 & 76.7 & 32.0 & 7.7 & 41.7 \\
\hline & Mean & 75.3 & 24.7 & 84.8 & 34.7 & 8.1 & 40.9 \\
\hline \multirow{5}{*}{ G.90 × Australian } & Sohag & 76.5 & 23.5 & 90.3 & 37.0 & 8.9 & 41.0 \\
\hline & El-Minia & 81.4 & 18.6 & 82.4 & 34.7 & 7.3 & 42.1 \\
\hline & Beni-Sueif & 77.5 & 22.5 & 86.4 & 36.3 & 8.2 & 42.0 \\
\hline & El-Faium & 75.9 & 24.1 & 86.1 & 36.4 & 8.4 & 42.3 \\
\hline & Mean & 77.8 & 22.2 & 86.3 & 36.1 & 8.2 & 41.8 \\
\hline
\end{tabular}




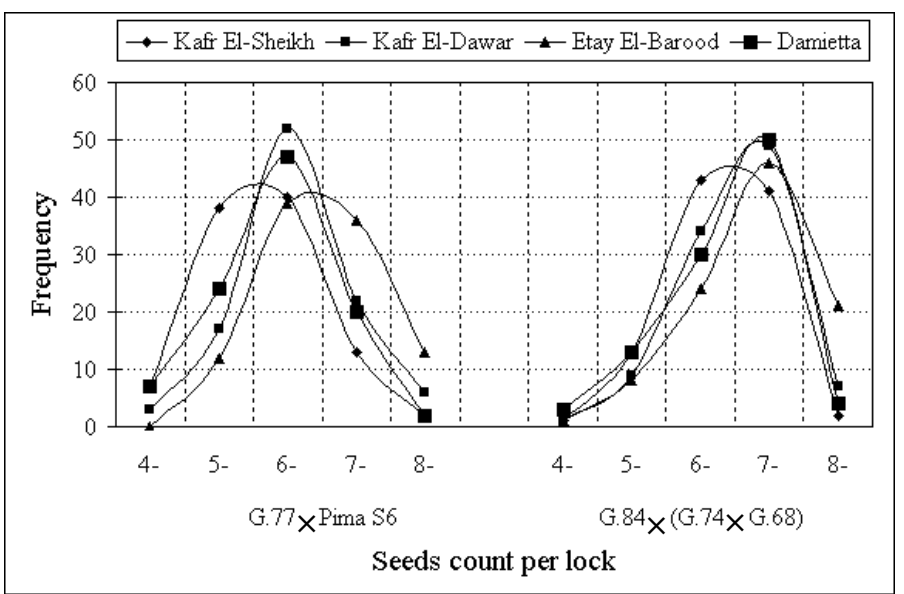

Figure 1. Normal distribution curves of seeds count per lock for the promising hybrids [G.77 × Pima S6 and G.84 × $(\mathrm{G} .74 \times$ G.68)] at 4 locations.

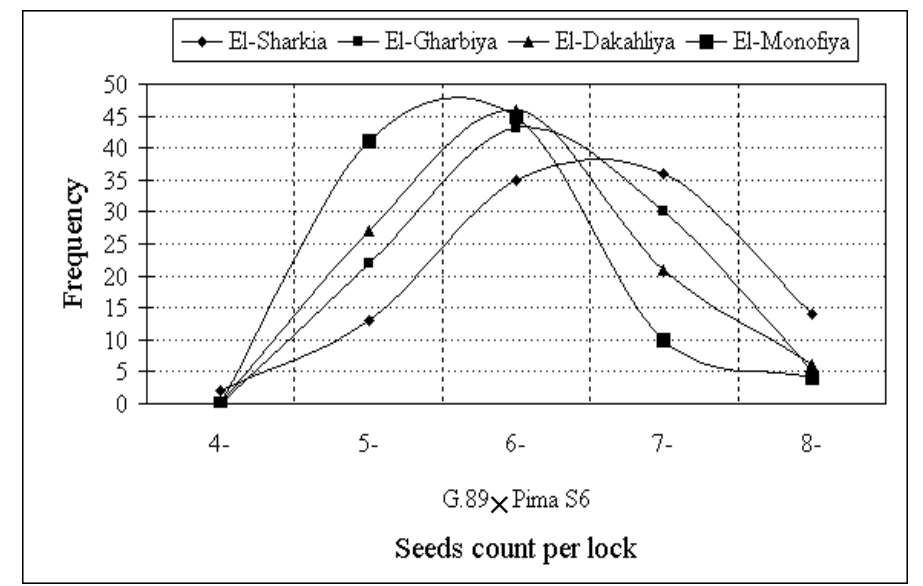

Figure 2. Normal distribution curves of seeds count per lock for the promising hybrid [G.89 $\times$ Pima S6] at 4 locations.

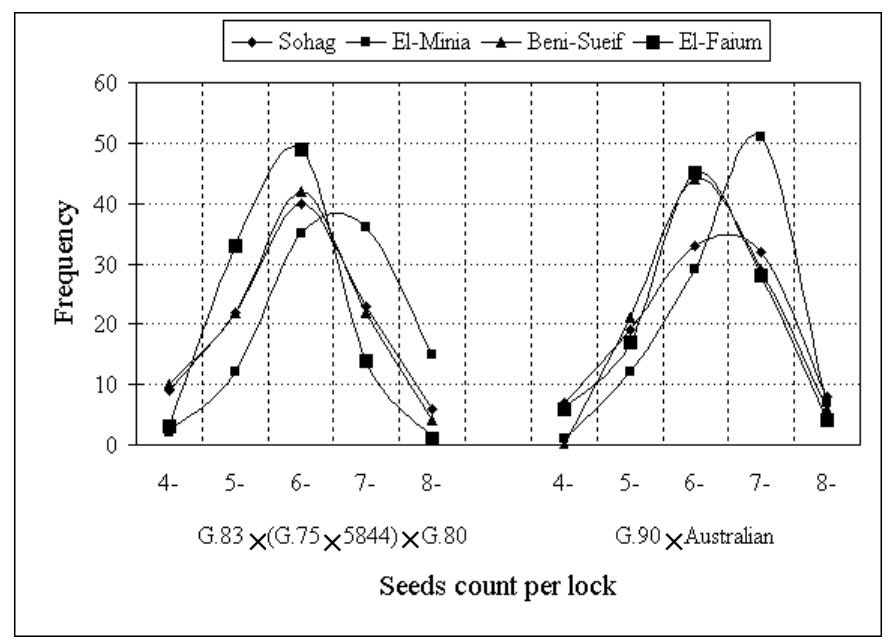

Figure 3. Normal distribution curves of seeds count per lock for the promising hybrids [G.83 × $(\mathrm{G} .75 \times 5844) \times \mathrm{G} .80$ and G.90 × Australian] at 4 locations. 


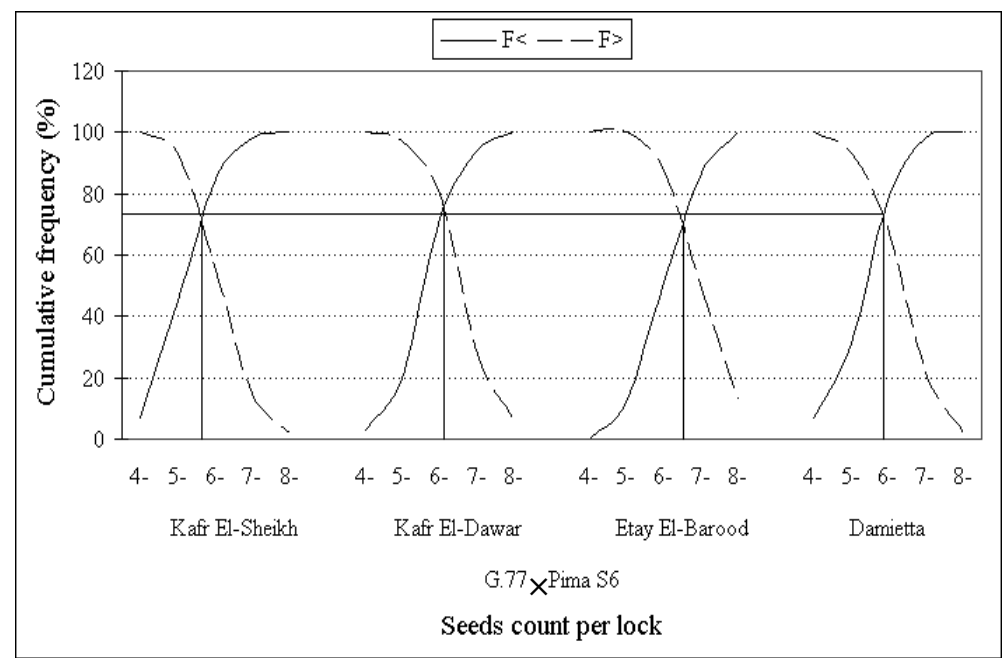

Figure 4. Cumulative frequency curves of seeds count per lock for the promising hybrid [G.77 $\times$ Pima S6] at 4 locations.

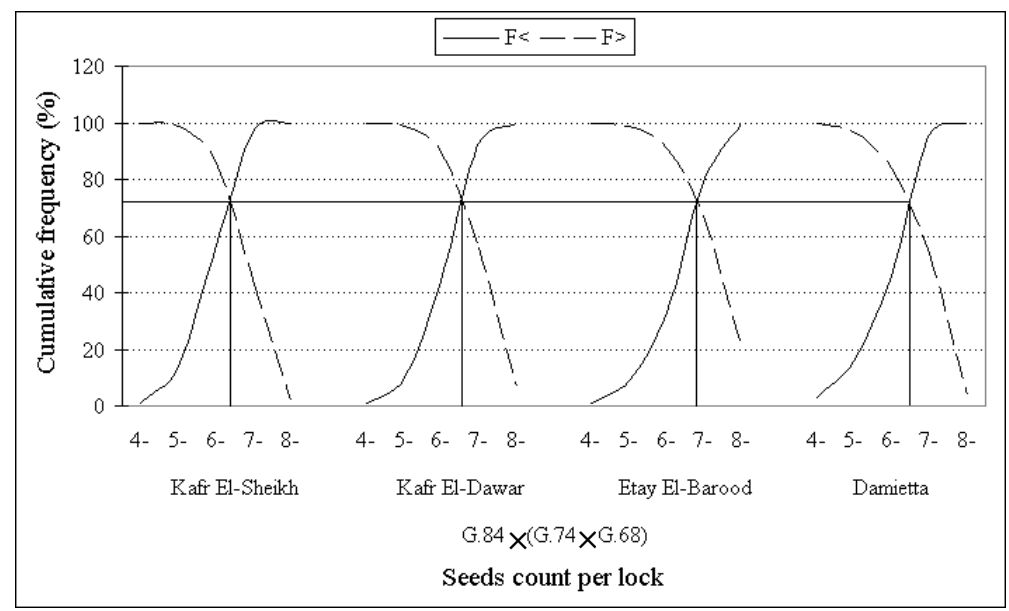

Figure 5. Cumulative frequency curves of seeds count per lock for the promising hybrid [G.84 × (G.74 × G.68)] at 4 locations.

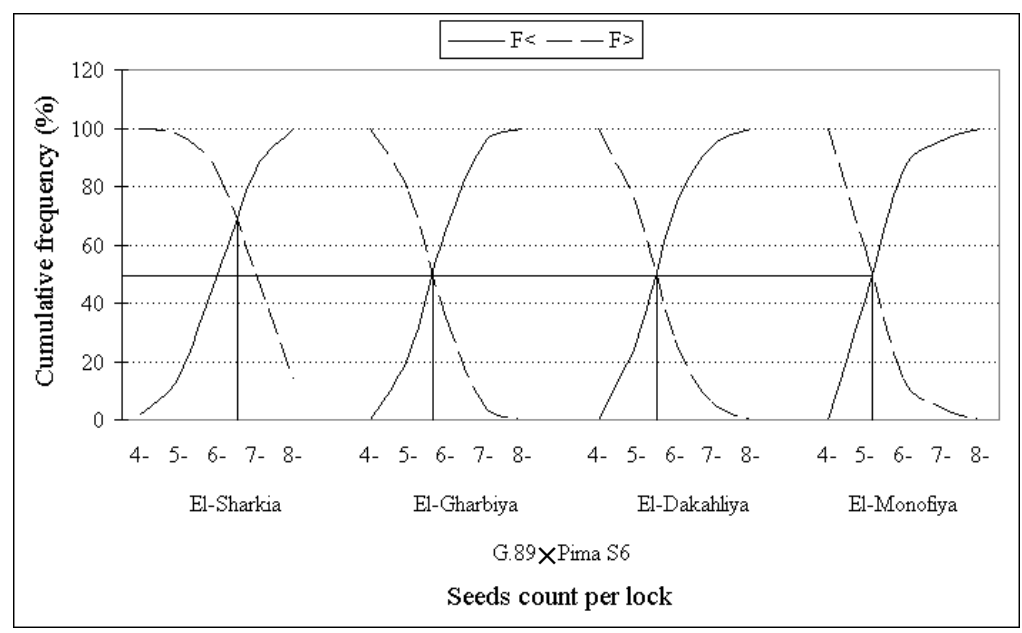

Figure 6. Cumulative frequency curves of seeds count per lock for the promising hybrid [G.89 $\times$ Pima S6] at 4 locations. 


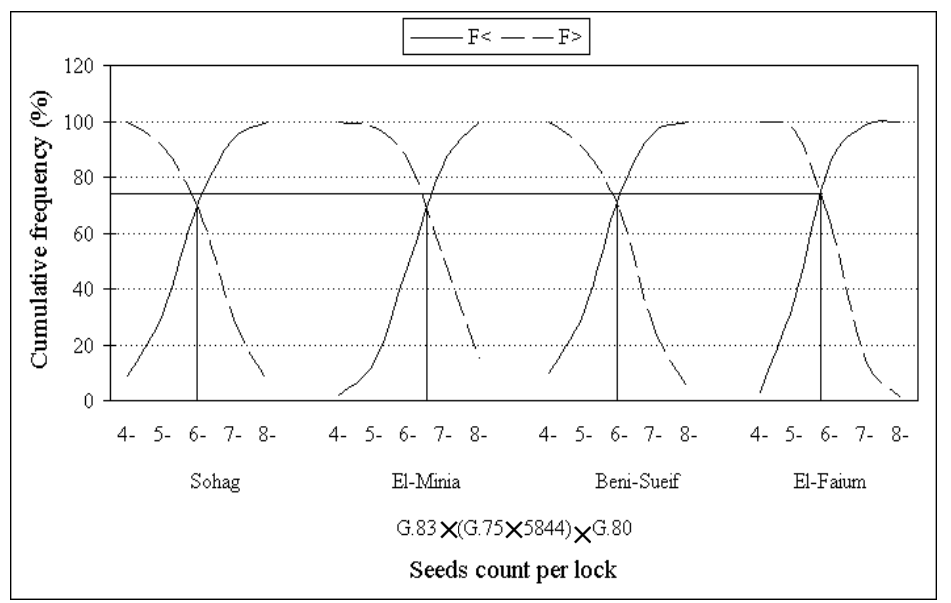

Figure 7. Cumulative frequency curves of seeds count per lock for the promising hybrid $[\mathrm{G} .83 \times(\mathrm{G} .75 \times 5844) \times \mathrm{G} .80$ ] at 4 locations.

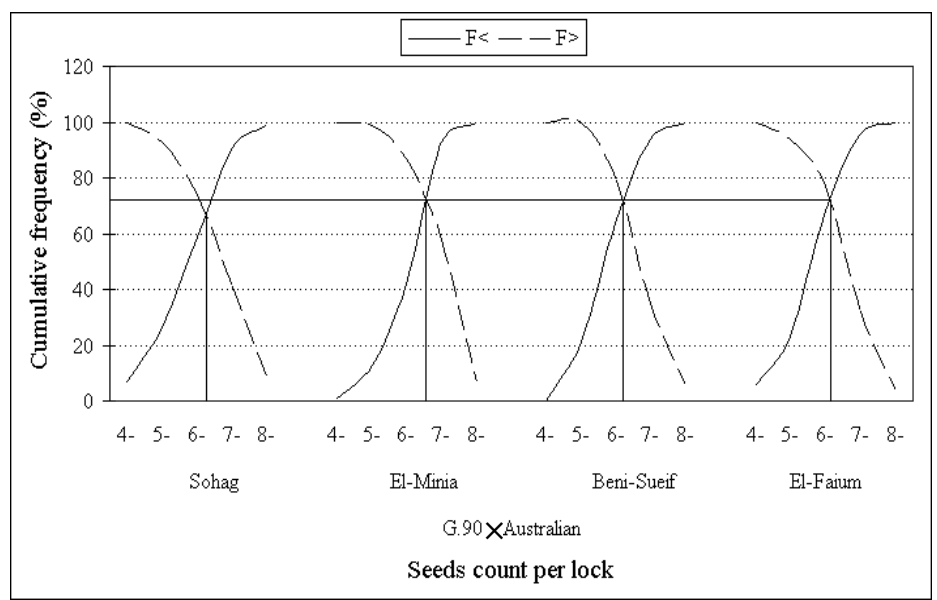

Figure 8. Cumulative frequency curves of seeds count per lock for the promising hybrid [G.90 $\times$ Australian] at 4 locations.

centages of locks possessing motes ranged from $18.8 \%$ for the promising hybrid [G.84 × (G.74 × G.68)] to 24.7 $\%$ for the promising hybrid [G.77 $\times$ Pima S6] and [G.83 $\times$ $(\mathrm{G} .75 \times 5844) \times$ G.80]. In general, the relative differences among the varieties were about the same from location to location. The varieties exhibited different behavior responses to environmental conditions. However, the percentages of locks with motes were higher for [G.77 $\times$ Pima S6] in Kafr El-Sheikh (29.4 \%) than [G.84 × (G.74 $\times$ G.68)] in Etay El-Barood (15.3\%). The importance of the influence of environmental factors and cotton cultivars on the development of motes is shown by the highly differences in the number of motes in seed-cotton samples representing different locations and cotton cultivars (Table 1). On the whole, environmental factors associated only with differences in place of growth, appeared to have much more influence on the number of motes developed than did varietal factors.

Figures 1-8 of normal distribution and cumulative frequency curves of locks with motes in 4-, 5-, 6-, 7-, and 8-seed per lock classes illustrate the mean, median and concentration the data around the mean for the 5 promising hybrids at the different locations. Its show that most of the locks for the promising hybrid at the different locations tends to cluster around the mean of 6 or 7 seeds per lock.

\subsection{Relation between Motes Percentage and Ginning Outturn}

The results are not entirely consistent, but in general and for most promising hybrids under study there is a fairly marked tendency for the lock index (the weight, in grams, of 100 locks), lint weight per 100 locks and lint percentage to decrease as the motes percentage increase (Figures 9, 10 and 12). It is true that certain varieties failed to show this tend, and some showed it to a much more pronounced degree than others. On the other hand, most of the promising hybrids under study tend to increase in the seed index (the weight, in grams, of 100 seeds) as the motes percentage increase (Figure 11). 


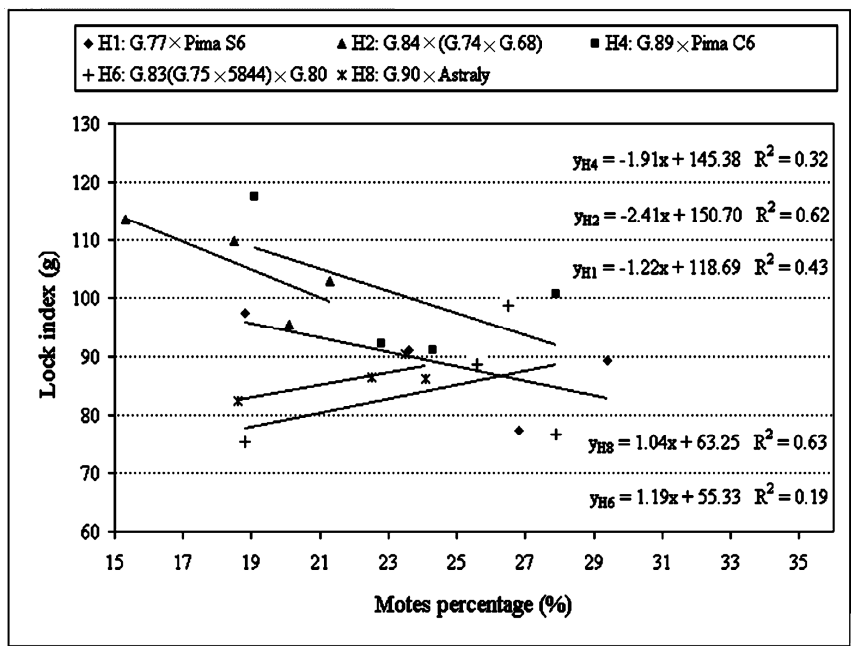

Figure 9. Relationship between lock index and motes percentage for the 5 promising hybrids.

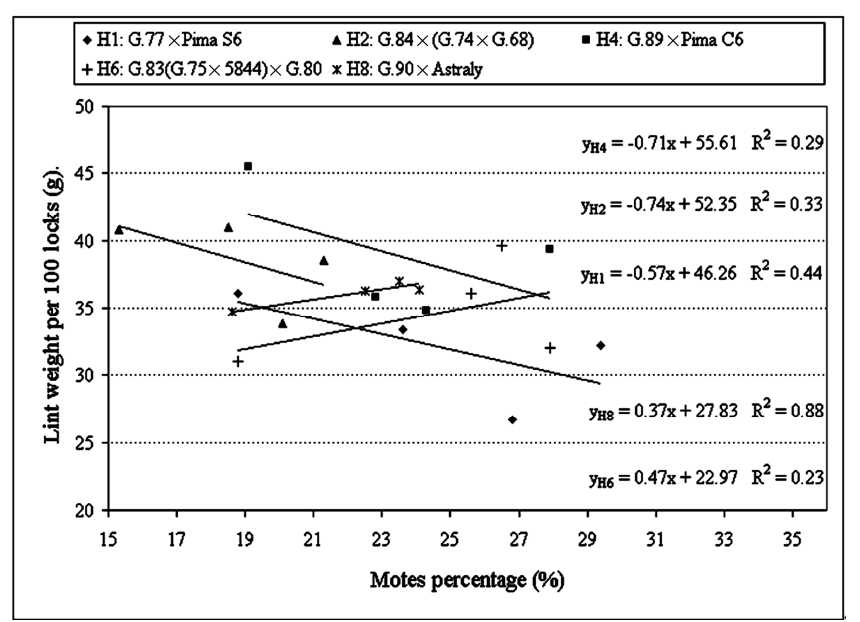

Figure 10. Relationship between lint weight per 100 locks and motes percentage for the 5 promising hybrids.

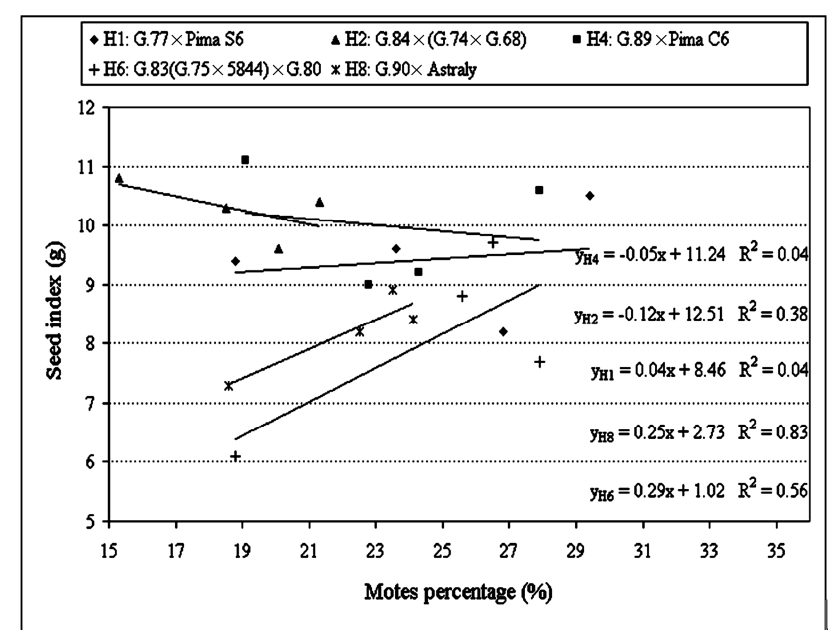

Figure 11. Relationship between seed index and motes per centage for the 5 promising hybrids. 


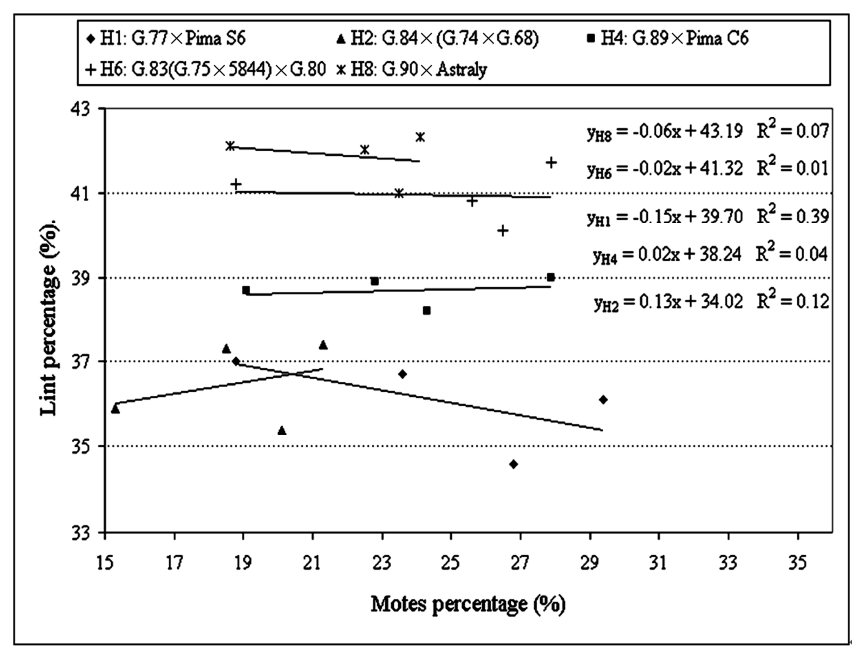

Figure 12. Relationship between lint percentage and motes percentage for the 5 promising hybrids.

For the promising hybrids [G.84 × $(\mathrm{G} .74 \times \mathrm{G} .68)$ and G.89 $\times$ Pima S6] the results show that as the motes percentage increased the lock index and lint weight per 100 locks decreased and the lint percentage increased this could be explained a result of the decreasing in seed index. But, for the promising hybrid [G.77 $\times$ Pima S6] the results show that as the motes percentage increased the lock index and lint weight per 100 locks decreased and the lint percentage decreased as a result of the increasing in seed index. while, for the promising hybrids [G.83 $\times$ $(\mathrm{G} .75 \times 5844) \times \mathrm{G} .80$ and G.90 $\times$ Australian] the results indicated that as the motes percentage increased the lock index and lint weight per 100 locks increased and the lint percentage decreased as a result of the increasing in seed index.

However, the increasing in seed index as a result of the increasing in motes percentage for some cotton cultivars growing at different environments could be explain the difference in behavior for these cotton cultivars in lint percentage.

\section{REFERENCES}

[1] Stewart, J.M. (1986) Integrated events in flower and fruit. In: Mauney, J.R. and Stewart, J.M., Ed., Cotton Physiology, The Cotton Foundation, Memphis, 261-300.

[2] Powell, R.D. (1969) Effect of temperature on boll set and development of Gossypium hirsutum. Cotton Growing Review, 46, 29-36.

[3] Fisher, W.D. (1973) Association of temperature and boll set. Proceedings of the Beltwide Cotton Production Research Conference, Phoenix, 9-10 January 1973, Na- tional Cotton Council of America, Memphis, 72-73.

[4] Pearson, N.L. (1949) Mote types in cotton and their occurrence as related to variety, environment, position in lock, lock size and number of locks per boll. USDA Technical Bulletins, 1000, U.S. Government Printing Office, Washington, DC.

[5] Davidonis, G.H., Johnson, A., Landivar, J. and Hinojosa, O. (1996) Influence of low-weight seeds and motes on the fiber properties of other cotton seeds. Field Crops Research, 48(2-3), 141-153.

[6] Mangialardi, G.J., Jr. and Meredith, W.R., Jr. (1990) Relationship of fineness, maturity, and strength to neps and seed-coat fragments in ginned lint. Transactions of the American Society of Agricultural Engineers, 33(4), 10751082.

[7] Davidonis, G.H., Johnson, A. and Landivar, J.A. (2000) Cotton mote frequency under rainfed and irrigated conditions. Journal of Cotton Science, 4(1), 1-9.

[8] Bolek, Y. (2006) Genetic variation among cotton (Gossypium hirsutum L.) cultivars for mote frequency. The Journal of Agricultural Science, 144(4), 327-331.

[9] Percy, R.G. (1986) Effects of environment upon ovule abortion in interspecific $F_{1}$ hybrids and single species cultivars of cotton. Crop Science, 26(5), 938-942.

[10] Miller, P.A., Comstock, R.E. and Harvey, H.F. (1958) Estimates of genotypic and environmental variances and covariance in Upland and their implication in selection. Agronomy Journal, 50, 126-131.

[11] Turner, J.H., Ramy, H.H., Jr. and Worley, S., Jr. (1976) Influence of environment on seed quality of for cotton cultivars. Crop Science, 16, 407-409. 